\title{
立塩用食塩水の簡易回収法
}

\author{
榎本則行・泉外喜雄・蓄安行雄 \\ (1959 年 12 月 17 日受理)
}

\section{A SIMPLE METHOD OF REGENERATING THE SALINE SOLUTION USED IN BRINE SALTING}

\author{
Noriyuki Enomoto, Tokio Izumi and Yukio TomrYasu*
}

\begin{abstract}
A saline solution once used in brine salting is usually considered to be out of use, because the bacteria and the soluble matters from fish body are liable to bring about such a bad effects on the fish brined in the used solution that degrade the quality of the product. How. ever, as a saline solution once used still contains a large quantity of salt, it is uneconomical to abandon the solution after using it only one time. In this point of view, the authors have devised a simple method of regenerating the used saline solution. This method and the results are outlined as follows:

1) After adding $\mathrm{N} / 5 \mathrm{HCl}$ at the rate of $0.9 \sim 1.0 \mathrm{cc}$. to $10 \mathrm{cc}$. of the used saline solution, the mixture is boiled for $30 \mathrm{~min}$. and then added with $2 \%$ Japanese acid clay. The filtrate obtained in this way is available again for salting after adjustment of its salt concentration.

2) For convenience' sake, the filtrate is generally made saturated with common salt, from which saline solutions of desirable concentrations for reuse can be readily prepared by dilution.

3) The ratio of $\mathrm{N} / 5 \mathrm{HCl}$ to be added is constant irrespective of the concentration of used saline solution.

4) The result of application of regenerated saline solutions to salting test indicates that there is hardly any difference in quality between the products brined in the regenerated saline solution and those in the new saline solution. Dissolution of tasteful matters such as amino acid from fish body into the saline solution can be depressed.
\end{abstract}

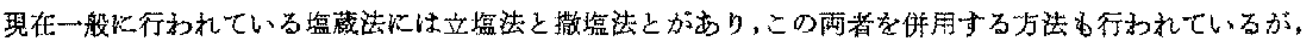

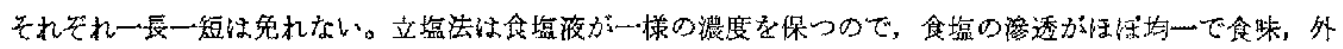

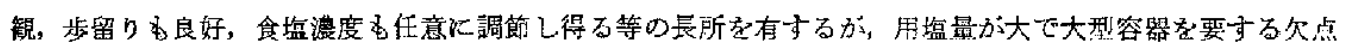
むむる。立塩法では使用食塩水を塩蔵の度に更新する場合と同一の食塩水を反覆使用する場合がある。同一

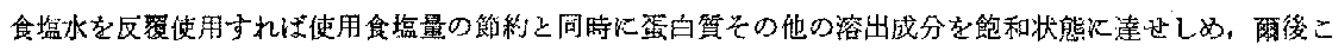

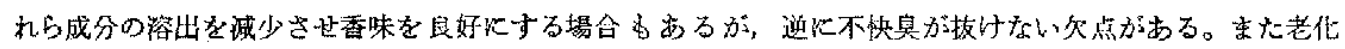

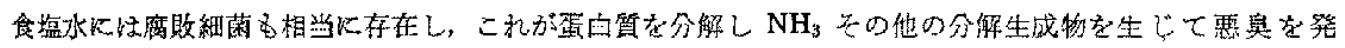
し、つぎの程蔵の際に魚体に附着して不良品を作ることが多い。したがつて立塩清では常に新しい食塩水を 用いることが推賞されているい。

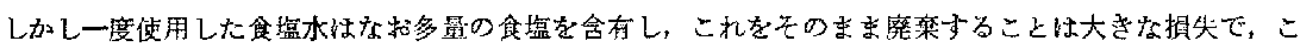

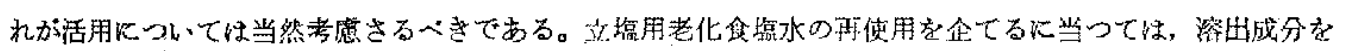

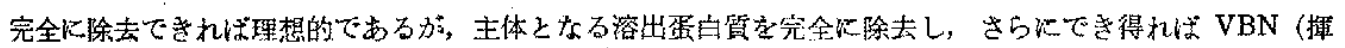

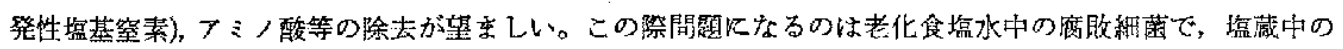

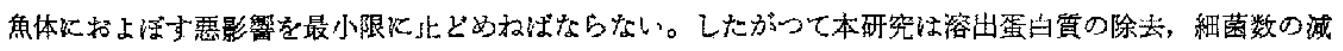

*九州大学脿学部承産化学教室 (Lab. Fish. Chem. Fac. Agr. Kyushu Univ., Fukuoka, Japan), 
少に重点を置いてなされた。

\section{実 験 方 法}

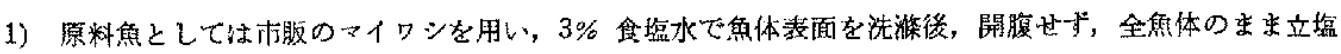

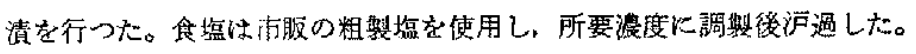

2) 定量 法

a) $\mathrm{NaCl}: \mathrm{N} / 10 \mathrm{AgNO}_{3}$ を以て滴定した值をその要 $\mathrm{NaCl}$ に換算した。

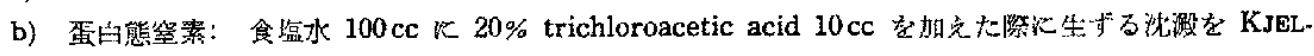
DAHL 法で測定した。

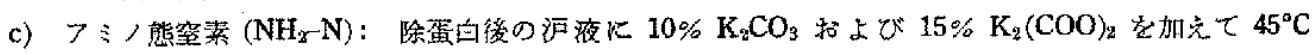
で 90 分間通気绻, VAN SLYKE 法で浿定した。

d) 揮発性塩基窑素 (VBN)：CONWAY の微量㧙散分析法Kよつた。

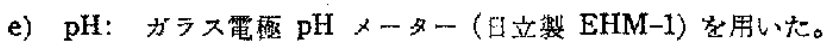

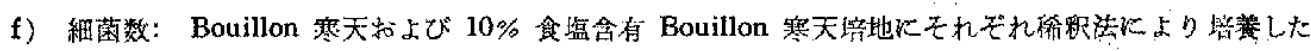
ものの 48 時間後の colony 数を討測した。

\section{实験䊀果抬よひ考寒}

\section{I. 食堛水可楁蛋白算の等域}

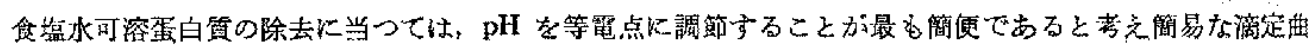

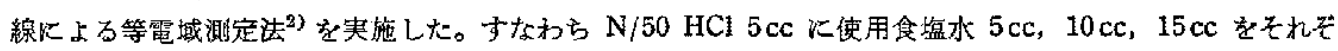

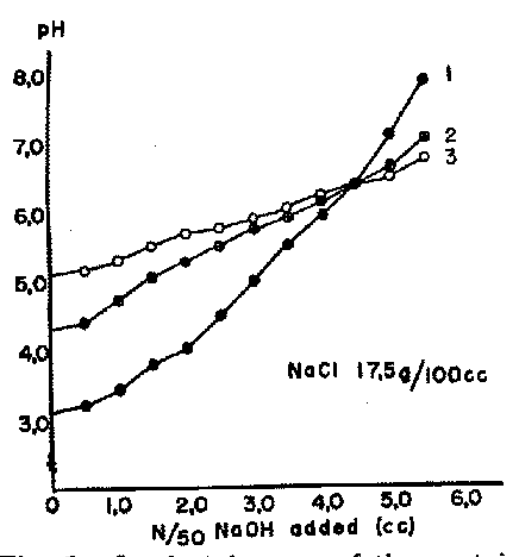

Fig. 1. Isoelectric zone of the protein dissolved into the brine from sardine.

1. $\mathrm{N} / 50 \mathrm{HCl} 5 \mathrm{cc}+\mathrm{Brine} 5 \mathrm{cc}$

2. $\mathrm{N} / 50 \mathrm{HCl} 5 \mathrm{cc}+$ Brine $10 \mathrm{cc}$

3. $\mathrm{N} / 50 \mathrm{HCl} 5 \mathrm{cc}+\mathrm{Brine} 15 \mathrm{cc}$

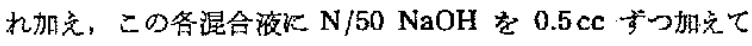
その都度混合液の $\mathrm{pH}$ を測定した。 $\mathrm{N} / 50 \mathrm{NaOH}$ の添加量

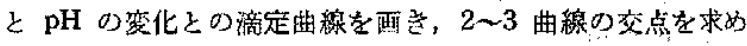
てその算電域とするち法である。

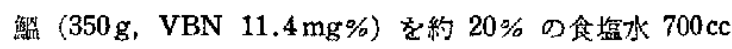

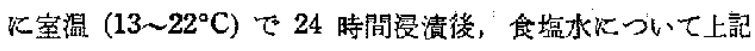
の方法で等電域を求めた。結果を Fig. 1 に西した。

こ机によると等電域は $\mathrm{pH}$ 6.38〜6.40 沈するしかし使

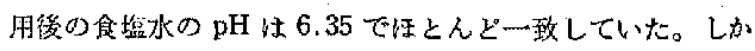

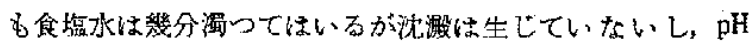

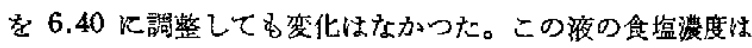

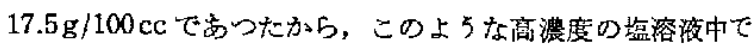

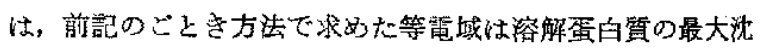
使を生ぜしる $\mathrm{pH}$ を示していないことが分る。しかし $\mathrm{pH}$

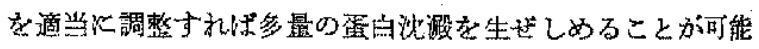

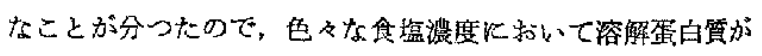
最大不溶解性を尔方 $\mathrm{pH}$ を求めることが必要となつた。

\section{II. 食㙁水可溶蛋白诈の除去}

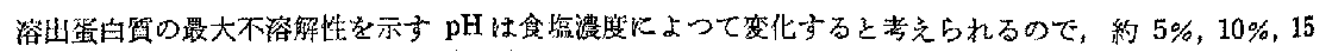

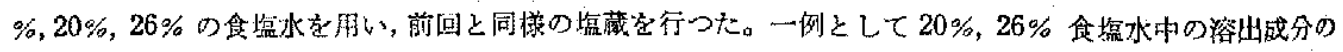
測定值を Table 1 K示した。蛋白質以外飞るかなりの溶出成分が認められる。

塩蔵後の飲塩水 $10 \mathrm{cc}$ K対し， N/5 HCl を添加した際の添加量と析出蛋白質の帘化忹 Fig. 2 のごとく

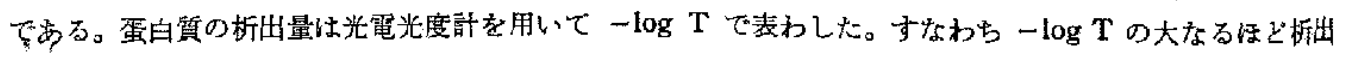


Table 1. Some characteristics of the brines used at different concentrations in fish salting.

\begin{tabular}{|c|c|c|c|c|c|c|c|c|c|}
\hline & \multicolumn{7}{|c|}{ Brine } & \multicolumn{2}{|c|}{ Fish (Sardine) } \\
\hline $\begin{array}{l}\text { Hour } \\
\text { of dips }\end{array}$ & $\begin{array}{l}\mathrm{NaCl} \\
\mathrm{g} / 100 \mathrm{cc}\end{array}$ & Volume & $\mathrm{pH}$ & $\underset{\text { mg } \%}{\text { Protein }-\mathrm{N}}$ & $\begin{array}{l}\mathrm{VBN} * \\
\mathrm{mg} \%\end{array}$ & $\begin{array}{c}\mathrm{NH}_{2}-\mathrm{N} \\
\mathrm{mg} \%\end{array}$ & $\begin{array}{l}\text { Bacterial count } \\
\qquad / \mathrm{cc}\end{array}$ & $\begin{array}{c}\text { Weight } \\
\mathrm{g}\end{array}$ & $\begin{array}{l}\mathrm{VBN} \\
\mathbf{m} \mathbf{g} \%\end{array}$ \\
\hline 0 & 21.9 & 780 & 7.34 & 0 & 0 & 0 & & 390 & 11.8 \\
\hline 20 & 17.1 & 794 & 6.32 & 13.1 & 3.43 & 16.7 & $8.6 \times 10^{4} \sim 1.2 \times 10^{6} \mid$ & 380 & 16.1 \\
\hline 0 & 28.9 & 590 & 7.22 & 0 & 0 & 0 & & 295 & 11.8 \\
\hline 20 & 25.5 & 610 & 6.12 & 11.6 & 2.37 & 15.9 & $8.6 \times 10^{4} \sim 9 \times 10^{4}$ & 281 & 15.6 \\
\hline
\end{tabular}

Fish : brine $=1: 2$ (in weight) *VBN : volatile basic nitrogen.

\section{量は大となる。}

因炕和いて 食塩搌度の高い方加服次 $3.36,3.75,3.91,4.06$,

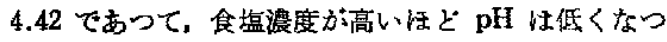
ている。しかし $\mathrm{N} / 5 \mathrm{HCl}$ 添加量の点から見ると $\mathrm{pH}$

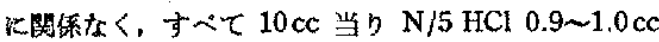
添加の々ころが最大不溶解性を示している。すなかち 使用食塩水の除蛋白を考光る場合， $\mathrm{pH}$ は考貟せず 常纪食塩水 $10 \mathrm{cc}$ 当り $\mathrm{N} / 5 \mathrm{HCl} 0.9 \sim 1.0 \mathrm{cc}$ 加党 ればよいことが分り非常に籍便である。

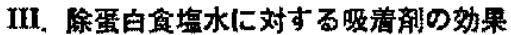

懢 (VBN $18.6 \mathrm{mg} \%$ ) 22 時間立程漬した食潪水 K N/5 HCl 所要量添加, 30 分故置後一部を阿過し た。汇夜は完全に透明であるが溦黄色を帯びておりり， これは血液炕由来した色と思われる。脱色敌よび

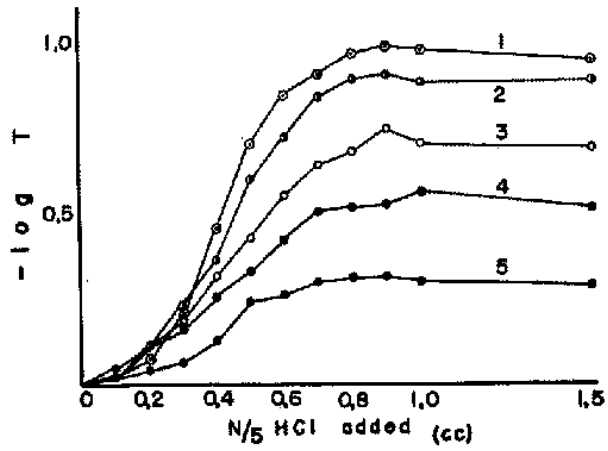

Fig. 2. Effect of salt concentration on precipitation of protein caused by add. ing $\mathrm{N} / 5 \mathrm{HCl}$ to $10 \mathrm{cc}$. brine. Concentration of $\mathrm{NaCl}(\mathrm{g} / 100 \mathrm{cc})$
(1) 4.8 ;
(2) 9.6 ;
(3) 13.3 ;

18.7 ; (5) 27.9 ,

Table 1 飞示されたことき VBN, $\mathrm{NH}_{3}-\mathrm{N}$ 等の除步を目的としてCelite, 酸性白土，佸性岸を加えてその 效果を見た。結果を Table 2 K示した。

Table 2. Effect of adsorbent addition on some characteristics of a brine previously treated with $\mathrm{N} / 5 \mathrm{HCl}$.

\begin{tabular}{|c|c|c|c|c|c|c|c|c|c|c|}
\hline & & & Sample & L* & & & & Sample & $\mathrm{H}^{*}$ & \\
\hline & $\begin{array}{c}\mathrm{NaCl} \\
\mathrm{g} / 100 \mathrm{cc}\end{array}$ & $\begin{array}{l}\mathrm{VBN} \\
\mathrm{mg} \%\end{array}$ & $\begin{array}{c}\mathrm{NH}_{2}-\mathrm{N} \\
\mathrm{mg} \%\end{array}$ & Protein & $\begin{array}{l}\text { Bacterial } \\
\text { count } \\
/ \mathrm{cc}\end{array}$ & $\mid \begin{array}{c}\mathrm{NaCl} \\
\mathrm{g} / 100 \mathrm{cc}\end{array}$ & $\begin{array}{l}\mathrm{VBN} \\
\mathrm{mg} \%\end{array}$ & $\begin{array}{l}\mathrm{NH}_{2}-\mathrm{N} \\
\mathrm{mg}_{\%} \%\end{array}$ & Protein & $\begin{array}{l}\text { Bacterial } \\
\text { count } \\
\text { /cc }\end{array}$ \\
\hline $\begin{array}{l}\text { Not added } \\
\qquad \text { (Control) }\end{array}$ & 16.1 & 4.33 & 20.4 & \pm & $5 \times 10^{2}$ & 24.6 & 2.49 & 19.3 & 走 & \\
\hline Celite $2 \%$ & 15.6 & 4.15 & 18.8 & \pm & $3 \times 10^{2}$ & 24.4 & 2.49 & 19.3 & \pm & \\
\hline $\begin{array}{c}\text { Celite } 1 \%+\text { Active } \\
\text { carbone } 1 \%\end{array}$ & 15.5 & 3.19 & 12.5 & - & $1.4 \times 10^{2}$ & 24.3 & 1.93 & 13.0 & - & \\
\hline Japanese acid clay & 15.5 & 3.29 & 17.5 & - & $3 \times 10^{2}$ & 24.3 & 2.28 & 17.3 & - & \\
\hline $\begin{array}{l}\text { Japanese acid clay } \\
1 \%+\text { Active } \\
\text { carbone } 1 \%\end{array}$ & 15.5 & 2.94 & 14.8 & - & $2 \times 10^{2}$ & 24.3 & 1.81 & 12.5 & - & \\
\hline
\end{tabular}

* Initial salt concentrations of sample $\mathrm{L}$ and $\mathrm{H}$ were about 20 and $26 \%$, respectively.

\& Proteinous residue was tested with $20 \%$ trichloroacetic acid. VBN of the salted sardine was $18.6 \mathrm{mg} . \%$. 


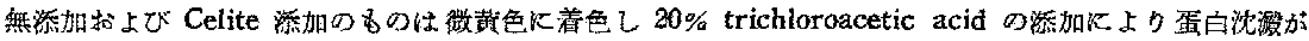

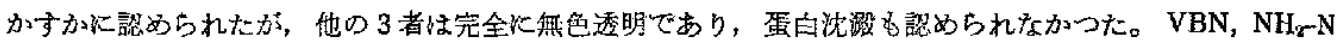

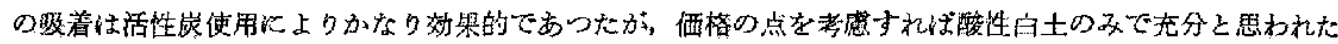

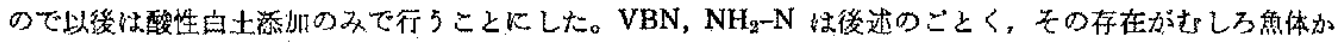
らの溶出を挪制する傾向が胃られるので强いて除去する必要はないる考充られる。

紐菌数については，回收处理前に $10^{4} \sim 10^{6} / \mathrm{cc}$ 位存在していたのでやや減少しているのが認められるが，

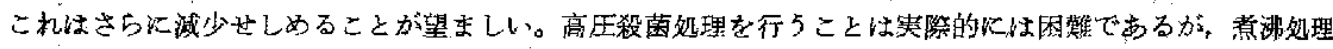
でる菌数の減少山充分に期待し得上引。

\section{IV. 塭葴温度が異つた場合の食塩水の回收試娩}

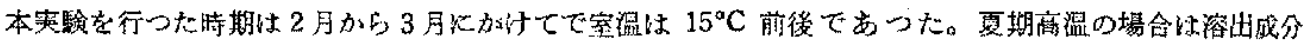

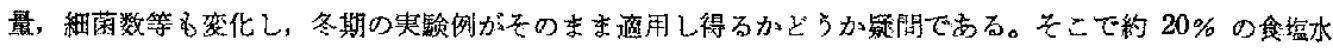
を用い，室温特よひ $30^{\circ} \mathrm{C}$ の㭌化器中で程藏を行つた。湘定結果は Table 3 と示した。

Table 3. Some characteristics of the brines used at different temperatures.

\begin{tabular}{|c|c|c|c|c|c|c|c|c|c|c|}
\hline \multirow{2}{*}{\multicolumn{2}{|c|}{ Condition $\begin{array}{c}\text { Hour } \\
\text { of } \\
\text { dips }\end{array}$}} & \multicolumn{7}{|c|}{ Brine } & \multicolumn{2}{|c|}{ Fish (Sardine) } \\
\hline & & $\begin{array}{c}\mathrm{NaCl} \\
\mathrm{g} / 100 \mathrm{cc}\end{array}$ & $\begin{array}{l}\text { Volume } \\
\text { cc }\end{array}$ & $\mathrm{pH}$ & $\begin{array}{c}\text { Protein } \\
-\mathrm{N} \\
\mathrm{mg} \%\end{array}$ & $\begin{array}{l}\text { VBN } \\
\text { mg \% }\end{array}$ & $\begin{array}{l}\mathrm{NH}_{2-\cdots} \mathrm{N} \\
\mathrm{mg} \%\end{array}$ & $\begin{array}{c}\text { Bacterial } \\
\text { count } \\
/ \mathrm{cc}\end{array}$ & $\begin{array}{c}\text { Weight } \\
\text { g }\end{array}$ & $\begin{array}{l}\text { VBN } \\
\text { mg\% }\end{array}$ \\
\hline \multirow{2}{*}{$\begin{array}{c}\text { Room } \\
\text { temperature } \\
\left(14 \sim 19^{\circ} \mathrm{C}\right)\end{array}$} & 0 & 20.4 & 810 & 7.30 & 0 & 0 & 0 & $4.8 \times 10^{2}$ & 810 & 10.9 \\
\hline & 20 & 13,9 & 855 & 6.20 & 42.9 & 6.3 & 32.3 & {$\left[\begin{array}{l}5.8 \times 10^{4} \\
\sim 2.6 \times 10^{5}\end{array}\right.$} & 784 & 15.7 \\
\hline \multirow{2}{*}{$30^{\circ} \mathrm{C}$} & 0 & 20.4 & 870 & 7.30 & 0 & 0 & 0 & & 865 & 10.9 \\
\hline & 20 & 12.6 & 955 & 5.80 & 34,6 & 14.8 & 96.9 & $\left|\begin{array}{l}8.6 \times 10^{\circ} \\
\sim 1.2 \times 10^{7}\end{array}\right|$ & 802 & 36.4 \\
\hline
\end{tabular}

Fish : brine $=1: 1$ (in weight)

塩蔵温度が異なる 2 種の食塩水に対し，それでれ $10 \mathrm{cc}$ 当り $1.0 \mathrm{cc} の$ 割合で $\mathrm{N} / 5 \mathrm{HCl}$ を矤加後, 細菌

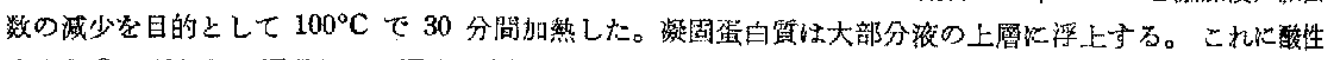

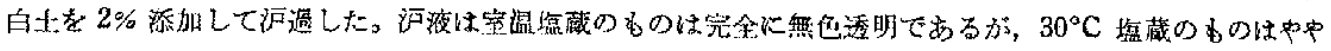

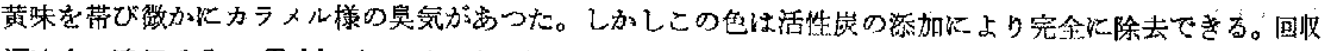
沪液中の溶解成分は Table 4 のごとくである。

Table 4. Some characteristics of the regenerated saline solution.*

\begin{tabular}{c|c|c|c|c|c|c}
\hline \hline & $\begin{array}{c}\mathrm{NaCl} \\
\mathrm{g} / 100 \mathrm{cc}\end{array}$ & $\mathrm{pH}$ & $\begin{array}{c}\text { Protein-N } \\
\mathrm{mg} \%\end{array}$ & $\begin{array}{c}\mathrm{VBN} \\
\mathrm{mg} \%\end{array}$ & $\begin{array}{c}\mathrm{NH}_{2}-\mathrm{N} \\
\mathrm{mg} \%\end{array}$ & $\begin{array}{c}\text { Bacterial } \\
\text { count } \\
/ \mathrm{cc}\end{array}$ \\
\hline $\begin{array}{c}\text { Room temperature } \\
30^{\circ} \mathrm{C}\end{array}$ & 13.7 & 3.59 & 0 & 6.2 & 32.1 & $1.3 \times 10^{2}$ \\
\hline
\end{tabular}

* $100 \mathrm{cc}$. brines in Table 3 were each treated with $10 \mathrm{cc}$. N/5 HCl and boiled for $30 \mathrm{~min}$, they were then added with $2 \%$ Japanese acid clay and filtered. This filtrate was used as the regenerated saline solution.

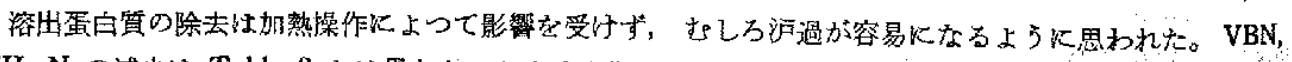

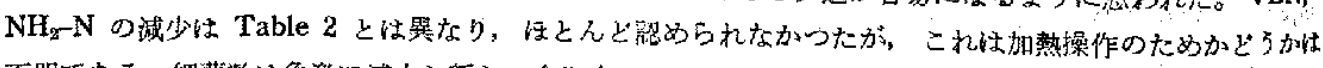

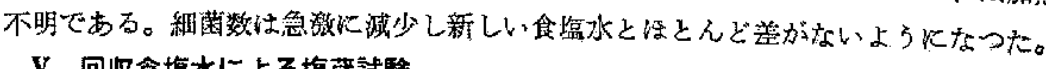

\section{V、回収食塩水による塩藏試験}

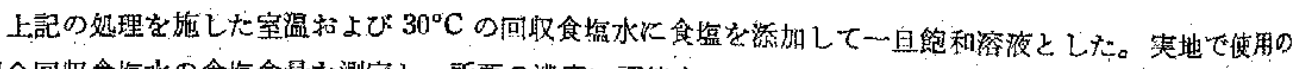

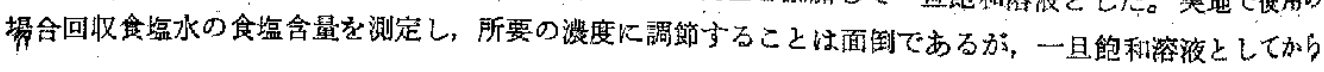


稀积すれば簡単比任意濃度の食知水を作り得ると考学たからである。

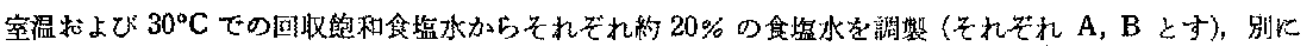

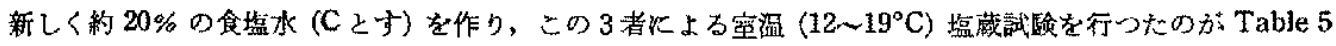
である。

Table 5. Brine salting test of sardine with the regenerated saline solution.

\begin{tabular}{|c|c|c|c|c|c|c|c|c|c|c|}
\hline & \multirow[b]{2}{*}{$\begin{array}{l}\text { Hour } \\
\text { of } \\
\text { dips }\end{array}$} & \multicolumn{2}{|c|}{ Fish (Sardine) } & \multicolumn{7}{|c|}{ Brine } \\
\hline & & $\begin{array}{c}\text { Weight } \\
\mathrm{g}\end{array}$ & $\begin{array}{l}\text { VBN } \\
\text { mag } \%\end{array}$ & $\begin{array}{c}\mathrm{NaCl} \\
\mathrm{g} / 100 \mathrm{cc}\end{array}$ & $\begin{array}{l}\text { Volume } \\
\text { cc }\end{array}$ & $\mathrm{pH}$ & $\begin{array}{c}\text { Protein } \\
-\mathrm{N} \\
\mathrm{mg} \%\end{array}$ & $\begin{array}{l}\mathrm{VBN} \\
\mathrm{mg} \%\end{array}$ & $\begin{array}{l}\mathrm{NH}_{2-\mathrm{N}} \mathrm{N} \\
\mathrm{mg} \%\end{array}$ & $\begin{array}{l}\text { Bacterial count } \\
\qquad / \mathrm{cc}\end{array}$ \\
\hline \multirow{2}{*}{ A } & 0 & 605 & 11.9 & 20.6 & 580 & 4.40 & 0 & 3.6 & 17.6 & \\
\hline & 20 & 570 & 17.9 & 14.0 & 620 & 5.79 & 25.4 & 6.4 & 45.5 & $3.9 \times 10^{4} \sim 1.8 \times 10^{5}$ \\
\hline \multirow{2}{*}{ B } & 0 & 750 & 11.9 & 21.1 & 750 & 3.70 & 0 & 9.9 & 54.9 & \\
\hline & 20 & 697 & 16.4 & 14.7 & 820 & 5.24 & 20.2 & 12.6 & 67.4 & $6.3 \times 10^{4} \sim 1.0 \times 10^{5}$ \\
\hline \multirow{2}{*}{$\mathrm{C}$} & 0 & 730 & 11.9 & 20.4 & 730 & 7.40 & 0 & 0 & 0 & \\
\hline & 20 & 670 & 17.2 & 14.7 & 780 & 6.23 & 26.2 & 5.6 & 33.5 & $1.9 \times 10^{6} \sim 2.5 \times 10^{5}$ \\
\hline
\end{tabular}

A was regenerated from brine once used at room temperature.

B was regenerated from brine once used at $30^{\circ} \mathrm{C}$.

C was a newly prepared brine.

$A$ and $B$ were first saturated with common salt and then diluted with water to a concentration of about $20 \%$ for brine salting test.

Fish : brine $=1: 1$ (in weight)

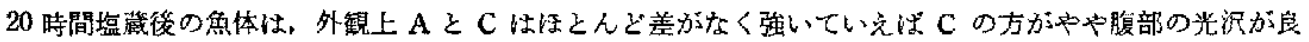

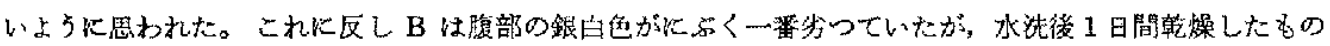

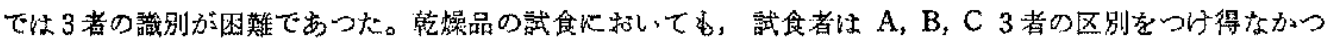
た。

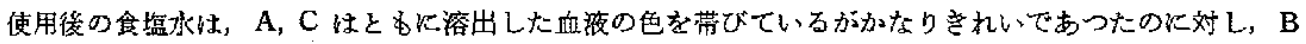

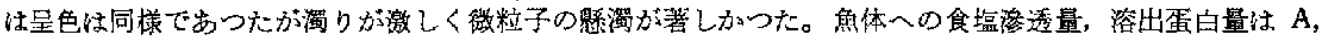

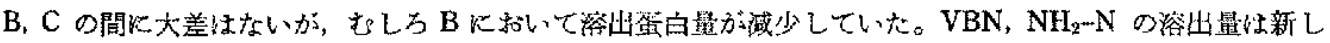

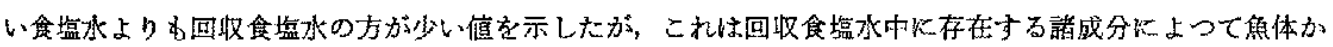
らの溶出が挪えられたるのと考えられ，魚体呈味成分の損失が少なくなることを意味して有利である。Bに

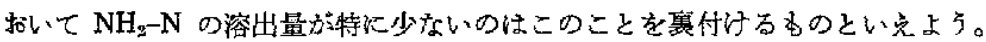

これら食塩水をさら火回収 処理した場合の測定檤を参考 までと Table 6 亿示した。 いすれれる無色透明で充分使用

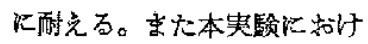

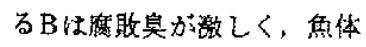
は腹务破えて噟敗初期の状態 を示していた。このような惠 条件の食程水です回取処理娄

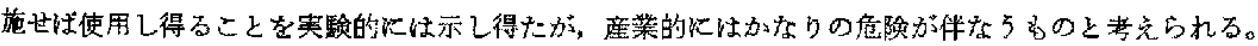

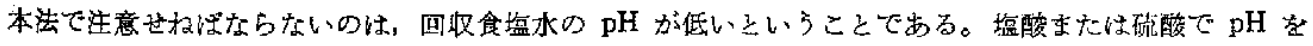

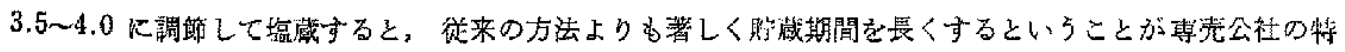




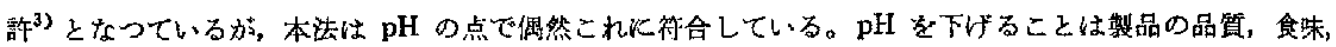

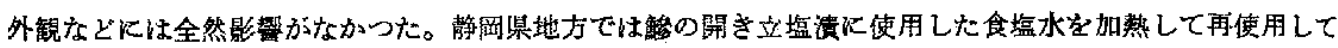

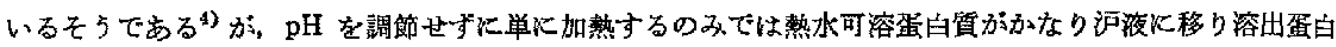

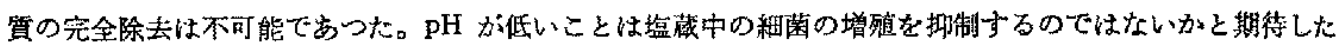
が，普通食壏水を比べて大差性なからた。

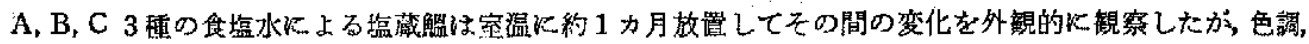
徽の発生具合, 乾燥速度, 油灌等にほをえど全く差異を認め得なかつた。

\section{雯 䄪}

1)立塩用食壏水の简易回取法を考案した。要点はつぎのことくである。

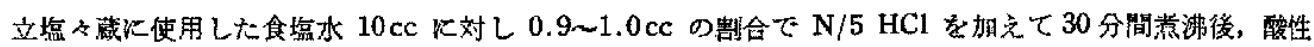
白士を $2 \%$ 加えて沪過すればよい。

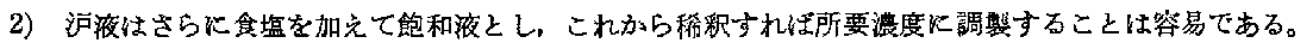

3) N/5 HCl の添加量注蓝葳使用した食塩水濃度に関係なく常に上記の割合でよい。

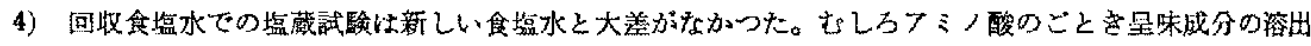

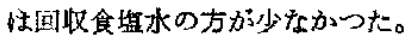

䅂りに本研究に有益な御意見を頂いた当鞂空豊水助数授に謝意を表する。

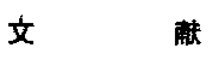

1) 森高次郎・橋本芳郎：“办産利用学”, 翰合書店, 東京, (1952), pp. 175.

2) 吉村寿人： “pH の理論と测定法”, 丸善, 東京, (1952), pp. 95 .

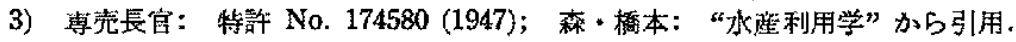

4) 静岡県水産試験場下田蜼四郎氏談。 